\title{
INFLUENCE OF FINANCIAL INCLUSION AND SOCIAL INCLUSION ON THE PERFORMANCE OF WOMEN - OWNED BUSINESSES IN LAGOS STATE, NIGERIA
}

\author{
Sajuyigbe, Ademola $\mathbf{S}$ (PhD, ACIB, ACIPS) \\ Department of Business Administration and Management \\ Osun State Polytechnic, Iree, Nigeria.
}

\begin{abstract}
Recognising the indispensable role of women owned enterprises in general economic development, the government of Nigeria have offered support to the development of women owned enterprises through financial intermediary, infrastructures and policy measures. Despite of these indicators, the state of micro entrepreneurship has yet to reach a satisfactory level and women enterprises continue to lag behind that of their male counterparts. This study therefore investigated the influence of financial inclusion and social inclusion on the Performance of Women - Owned Businesses in Lagos State, Nigeria. The population of this study comprised all four thousand six thousand sixty three (4,663) women-owned Micro, Small and Medium Enterprises (MSMEs) registered with SMEDAN while three hundred and fifty seven (357) were selected as a sample size for the study. The data collection instruments for the study were structured questionnaire and personal interview. Data were analyzed with the aid of Multiple Regression (Ordinary Least Square Estimation) and Pearson Product Moment Correlation Coefficient. Results showed that financial inclusion and social inclusion have positive and significant influence on women-owned businesses performance. Additionally, financial inclusion and social inclusion jointly contribute about $42.9 \%$ to the performance of women -owned businesses. Results also indicated that social inclusion $\left(r=0.543^{* *}\right)$ is positively and significantly related with the financial inclusion. The therefore recommended that government should have a policy in place through its financial regulator to encourage financial institutions to diversify their branch networks in the country and government should also have policies and regulatory frameworks in place that will close the gender gap in financial inclusion and social inclusion.
\end{abstract}

KEYWORDS: Financial Inclusion, Social Inclusion, Entrepreneurship, Business Performance

\section{Introduction}

The micro enterprises sector has been regarded as a major factor contributing to economic growth and sustainable development. Studies have described micro enterprise as a driving force for sustainable development in both developed and developing economies (Munoz, 2010; Odeh, 2005; Sharma, Sapnadua \& Hatwal, 2012). According to Oboh (2004), micro enterprises contribute to the increase entrepreneurship, enhance regional economic balance through industrial dispersal and generally promote effective resource utilization that are considered to be critical in the area of engendering economic development. Wasihun and Paul (2010) revealed that micro enterprises are important to women especially in Africa countries, because they provide opportunity for self-employment which represents a chance to exploit their potentials. Today, many opportunities to start new businesses and international support are available to women entrepreneurs. Female-run enterprises are steadily growing all over the world, contributing to household income and growth of national economies (Kalpana, 2016). 
In Nigeria, the spectrum of women in entrepreneurship often ranges from Home-Based Businesses (HBB) to Micro, Small and Medium Enterprises (MSMEs). They contribute more that than $97 \%$ of all enterprises, $60 \%$ of the nation's Gross Domestic Product (GDP) and 94\% of the total share of the employment (Ndubusi, 2004). Recognizing the indispensable role of women owned enterprises in general economic development, the government of Nigeria and Non-Government Organizations (NGOs) have offered support to the development of women owned enterprises through financial intermediary, infrastructures and policy measures. Despite of these indicators, the state of micro entrepreneurship has yet to reached a satisfactory level and women enterprises continue to lag behind that of their male counterparts, thus hindering them from fully optimizing their economic potential (Ademola, 2016).

Financial inclusion has been recognized as one of the factors that influence micro, small and medium enterprises growth and development. Financial inclusion is about the delivery of banking services at an affordable cost to the large sections of disadvantaged and low-income groups. Centre for Financial Inclusion (2013) described financial inclusion as a state in which all people who can use financial services have access to a complement of quality financial services, provided at affordable prices, in a convenient manner and with dignity for the clients. Clark (2013) asserted that financial inclusion helps people to diversify or increase income stream in the house, provides liquidity/cash flow; absorbs shock of adversity by building assets which enables client to cope with loss through consumption smoothing, thus avoiding the sale of productive assets.

In addition to financial inclusion, social inclusion has also been identified as one of the factors that influence micro, small and medium enterprises performance. Social inclusion is the removal of institutional barriers and the enhancement of incentives to increase access by diverse individuals and groups to development opportunities. According to Daniel (2001), social inclusion focusing on creating conditions for equal opportunities and equal access for all, is considered to be useful when describing the actual process involved in promoting social integration.

Inclusive financial and social arrangement are becoming policies issues in both developed and developing nations of the world as they have been perceived as veritable tools for micro, small and medium enterprises performance. Financial inclusion and social inclusion of women are essential for gender equality. They empower women and give them greater control over their financial and social life (Aker, Boumnijel, McClelland, \& Tierney, 2014; Ashraf, Karlan \& Yin, 2010).

\section{Statement of the Problem}

Entrepreneurship literatures have acknowledged the desire by women to be financially and socially independent. According to Arjan (2016), globally, one-in-three formally registered businesses are owned by women (IFC estimate). Small and Medium-Sized Enterprises (SMEs) account for 80 per cent of jobs world-wide, and women tend to be over-represented in, and own, smaller enterprises. Despite the significant contributions of women entrepreneurs to the economic development, women have been financially and socially marginalized. In line with this observation, Demirguc-Kunt, Klapper and Singer (2013) noted that women's lower level of financial literacy/capability; time and mobility constraints; poor access to information and networks; cultural and gender norms have been major constraints to women -owned businesses growth and development.

Financial inclusion and social inclusion have received a lot of research attention in developed and developing nations and they have measured and conceptualized in many different ways. However, the constructs have not been explored and they still remain challenging constructs in Nigeria. This study therefore intends to fill gap in knowledge by examining the influence of financial inclusion and social inclusion on women-owned businesses performance in Lagos State, Nigeria.

\section{Research Objectives}

The main objective of the study was to examine the influence of financial inclusion and social inclusion on women-owned businesses performance in Lagos State, Nigeria. Other specific objectives are;

i. To determine the influence of financial inclusion and social inclusion on women-owned businesses performance in Lagos State, Nigeria.

ii. To assess the relationship between financial inclusion and social inclusion. 


\section{Research Questions}

i. To what extent do financial inclusion and social inclusion influence women-owned businesses performance in Lagos State, Nigeria?

ii. Is there any significant relationship between financial inclusion and social inclusion?

\section{Research Hypotheses}

$\mathrm{H}_{\mathrm{ol}}$ : Financial inclusion and social inclusion have no significant influence on women-owned businesses performance in Lagos State, Nigeria

$\mathrm{H}_{\mathrm{o2}}$ : There is no significant relationship between financial inclusion and social inclusion.

\section{Justification for the Study}

This study is relevant and significant because it will deal with a contemporary issue. Financial exclusion and social exclusion have been pointed as major drivers of poverty; hence, financial inclusion and social inclusion are attracting worldwide attention. The study will offer the field insight into the relationship between financial inclusion, social inclusion and women owned businesses performance in Nigeria. The study is expected to contribute to existing literatures on financial inclusion and social inclusion in Nigeria and the result of this research work will serve as input for other researchers who interested in research on financial inclusion and social inclusion.

\section{REVIEW OF RELATED LITERATURE}

\section{Concept of Financial Inclusion}

Financial inclusion is well known and well documented. Nevertheless, much of the information on approaches to financial inclusion still lacks sex-disaggregated data, and thus maintains the prevailing gender gap in the access that women and men have to financial products and services globally (Stephen, 2011; Nwanko \& Nwanko, 2014). Financial inclusion or inclusive finance is whereby effort is made to ensure that all households and businesses, regardless of levels of income are able to effectively access and use appropriate financial services they need to improve their lives (FATF, 2011; Stephen, 2011; Nwanko \& Nwanko, 2014). Chakraborty (2012) defined financial inclusion as the process of ensuring access to appropriate financial product and services needed by vulnerable groups such as weaker societal sections and low income groups at an affordable cost in a fair and transparent manner by mainstream institutional players, thus making an inclusive financing arrangement critical aspects in the context of economic growth and development of any economy.

Rangarajan Committee (2008) also defined inclusion as the process of ensuring access to financial services as well as timely and adequate credit where needed by groups at an affordable cost. Centre for Financial Inclusion (2013) described financial inclusion as a state in which all people who can use financial services have access to a complement of quality financial services, provided at affordable prices, in a convenient manner and with dignity for the clients. Clark (2013) noted that financial inclusion helps people to diversify or increase income stream in the house, provides liquidity/cash flow; absorbs shock of adversity by building assets which enables client to cope with loss through consumption smoothing, thus avoiding the sale of productive assets.

\section{Concept of Social Inclusion}

Social inclusion gained prominence in public discourse after inclusion was incorporated as one of the four pillars in Poverty Reduction Strategy Paper (PRSP). The concept of social inclusion is similar to that of social integration. However, social inclusion, focusing on creating conditions for equal opportunities and equal access for all, is considered to be useful when describing the actual process involved in promoting social integration (Laxmi, 2012; Manandhar, 2008; Daniel, 2001; Seel, 2007; Leduc, 2005). Social inclusion is also often more easily accepted as a policy goal, as it clearly eliminates a connotation of assimilation that some associate with the term "integration" not all individuals and/or groups in societies are eager to be "integrated" into mainstream society, but all strive to be included (Manandhar, 2008; Daniel, 2001; Leduc, 2005).

According to Rao and Walton (2004), the overall goal of social inclusion policy is to build a just society devoid of discrimination, harness the full potential of all social groups regardless of sex or circumstance, promote the 
enjoyment of fundamental human rights and protect the health, social, economic and political well-being of all citizens, in order to achieve equitable rapid economic growth (Laxmi, 2012; Manandhar, 2008; Seel, 2007). It also aims to evolve an evidence-based planning and governance system where human, social, financial and technological resources are efficiently and effectively deployed for sustainable development (Seel, 2007; Silver, 2007; Leduc, 2005). Laxmi (2012) observed that social inclusion is the removal of institutional barriers and the enhancement of incentives to increase the access of diverse individuals and groups to development opportunities. It seeks to bring about system level institutional reform and policy change to remove inequities and gives some individuals and groups more opportunity to realize their agency (Seel, 2007; Rao \& Walton, 2004).

\section{Financial Exclusion and Social Exclusion and their effect on Women - Owned Business Performance}

The advocacy for women's economic empowerment has been growing over the last decade. The number of private actors promoting this has expanded significantly. Studies confirmed that women owned over $90 \%$ of businesses especially in informal sector (Akpodono, 2016; United Nations, 2014; Vossenberg, 2013). Data on women - owned small and medium enterprises suggests that these enterprises contribute about half of total employment, more than $30 \%$ of total gross domestic product. Also, one out of five units exported is produced in the small and medium sector in Nigeria (Central Bank of Nigeria, 2009).

Despite of this report, financial exclusion and social exclusion have bedevilled the performance of women -owned businesses in Nigeria. In line with this opinion, Minniti and Naudé (2010) observed that despite growing rates of female entrepreneurship and increasing education levels, women-owned enterprises are almost uniformly disadvantaged. McKinsey Global Institute (2015) also noted that women are often severely disadvantaged, compared to men in accessing facilities for saving or borrowing money. Hallward-Driemeier (2013) also discovered that there are gender gaps in education. Most of skills and business training tends to be targeted towards men.

Studies also confirmed that customs, lack of formal rights and access to justice have restricted women to have right to manage property, conduct business, or travel without their husbands' consent (Bruhn \& McKenzie, 2013; Duflo, 2012; Duryea \& Morales, 2011; Bruhn, 2009; Hundley, 2001). ILO (2015) asserted that women have inadequate access to education, assets, finance, information on trade regulations and procedures, market linkages, etc. Women's care responsibility and time burden create a fundamental barrier to engagement in global trade activities (ILO, 2015).

\section{Conceptual Framework}

\section{Strategies to Achieve Adequate Financial Inclusion and Social Inclusion}

The model explains the relationship between the variables under study; it explains financial inclusion and social inclusion strategies as independent variables while women-owned businesses performance as the dependent variable. 


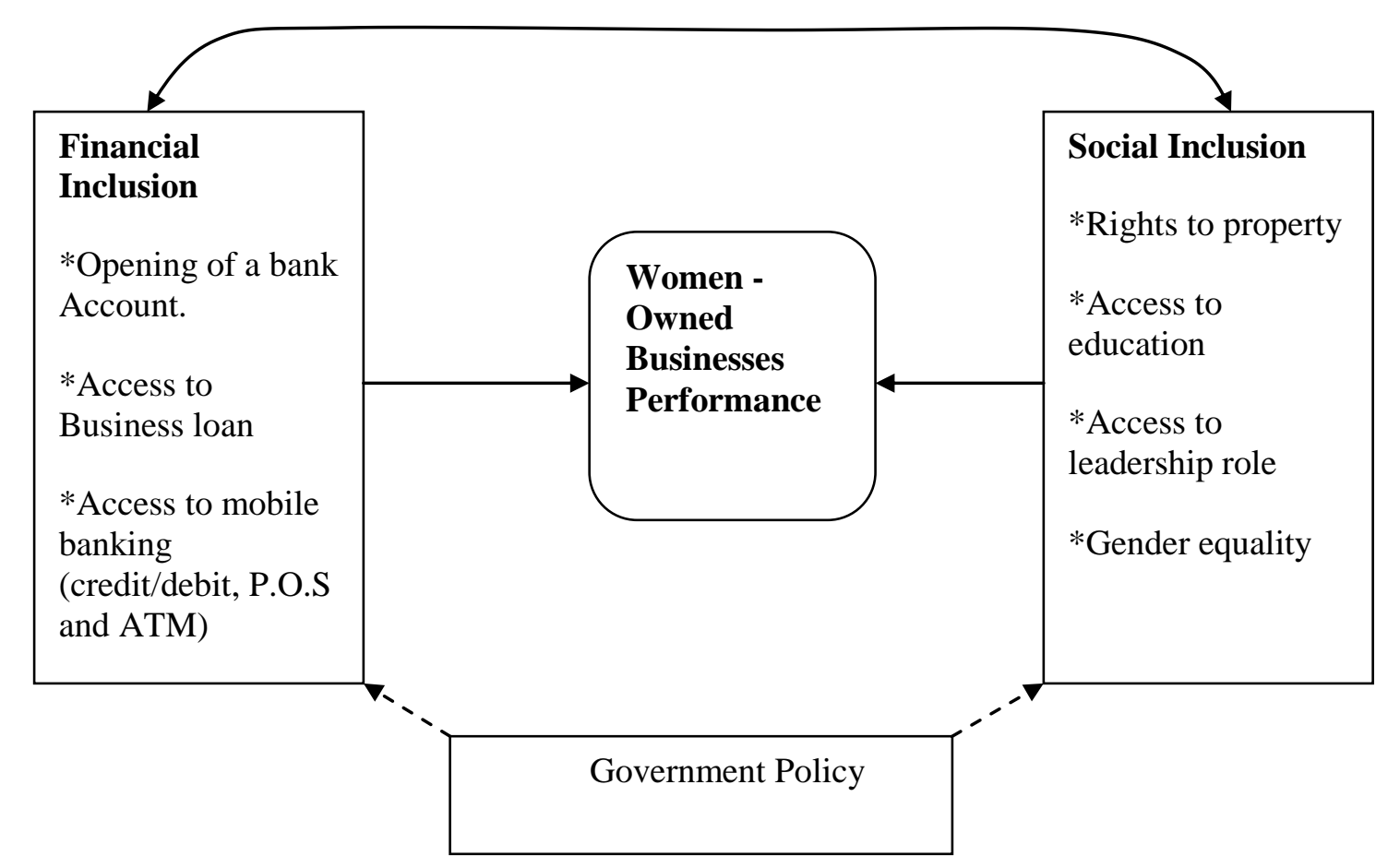

\section{Figure 1: Conceptual Model}

Figure 1 presents a summary diagram of the proposed causal model for the prediction of women -owned businesses performance from the concepts: Financial inclusion such as opening of account by women entrepreneurs, access to business loan, access to mobile banking (Utilization of Credit/Debit Cards, Point of Sales, Automated Teller Machine) and social inclusion such as women right to property, access to education, access to leadership role and gender equality. The model specifies the role of government policy as a mediator of the effect of financial inclusion and social inclusion on women-owned businesses performance. In this section the basis of the proposed conceptual framework is presented and the hypotheses regarding the relationships between the variables are specified.

\section{Methodology}

Study Area: This research work was carried out among the women entrepreneurs in Lagos State of Nigeria. The choice of this state is based on the fact that it has highest number of women -owned businesses in the country (SMEDAN/NBS, 2013).

Research Design: Descriptive survey research design was employed to examine the influence of financial inclusion and social inclusion on women -owned businesses performance.

Study Population and Size: The population of this study will comprise all four thousand six thousand sixty three $(4,663)$ women-owned Micro, Small and Medium Enterprises (MSMEs) registered with SMEDAN while three hundred and fifty seven (357) were selected as a sample size for the study, based on the formula suggested by Slovins (1960).

Data Collection Instruments: The data collection instruments for the study were structured questionnaire and personal interview. The research instruments were administered and retrieved personally by the researchers with the aid of one research assistant. 
Validity and Reliability of the Instruments: The instruments for the study were submitted to a panel of experts from Lagos State University, Ojoo, Nigeria and University of Lagos, Nigeria respectively for validation. The reliability of the instruments was determined through Cronbach's Alpha internal-consistency methods.

Method of Data Analysis: Data were analyzed with the aid of Multiple Regression (Ordinary Least Square Estimation) and Pearson Product Moment Correlation Coefficient

\section{Model Specification}

To examine the influence of financial inclusion and social inclusion on women-owned businesses performance, financial inclusion is measured by accessibility to account opening, accessibility to business loans and accessibility to mobile banking. Social inclusion is measured by women rights to property, accessibility to education, accessibility to leadership role and gender equality, while women-owned businesses performance was measured by ability to meet target profit level, sales growth, customer satisfaction and level of repurchase

Mathematically, the model is expressed as follows;

Women - Owned Businesses Performance $=\mathrm{f}\left(\mathrm{X}_{1}, \mathrm{X}_{2}\right)$ equ 1

Women - Owned Businesses Performance $=\beta 0+\beta_{1} X_{1}+\beta_{2} X_{2}+\mu \mathrm{i}$ .equ 2

where;

a priori expectation is $\beta_{1} . . \beta_{2}>0$

$\mathrm{X}_{1}=$ Financial inclusion; $\mathrm{X}_{2}=$ Social inclusion .

$\mu \mathrm{i}=$ Disturbance Term

$\beta=$ Intercept

$\beta_{1}-\beta_{2}=$ Coefficient of the independent variables.

\section{Results and Discussion}

\section{Influence of Financial Inclusion and Social Inclusion on Women-Owned Business Performance}

The result in Table 1 shows that financial inclusion and social inclusion have positive and significant influence on women-owned businesses performance. Additionally, financial inclusion and social inclusion jointly contribute about $42.9 \%$ to the performance of women -owned businesses. The estimated Durbin - Watson value of 1.822 clears any doubts as to the existence of positive first order serial correlation in the estimated model. The model was constructed to test the null hypothesis that financial inclusion and social inclusion have no influence on womenowned businesses performance in Lagos, Nigeria. The F-statistic of 139.520 indicates that the overall regression plane is statistically significant. Therefore, null hypothesis is rejected while alternative hypothesis is accepted.

Implication of this finding is that if women are financially and socially inclusive (access to business loan, access to mobile banking, access to education, rights to property, access to leadership role and gender equality) in Nigeria, the levels of women entrepreneurship will be high.

Table 1: Regression Results

\begin{tabular}{|c|c|c|c|c|c|}
\hline $\mathrm{R}$ & R Square & $\begin{array}{l}\text { Adjusted } \\
\text { R Square }\end{array}$ & $\begin{array}{l}\text { Std. Error of } \\
\text { the Estimate }\end{array}$ & \multicolumn{2}{|c|}{ Durbin-Watson } \\
\hline $.655^{\mathrm{a}}$ & .429 & .426 & .558 & \multicolumn{2}{|l|}{1.822} \\
\hline & Sum of Squares & Df & Mean Square & $\mathrm{F}$ & Sig. \\
\hline $\begin{array}{l}\text { Regression } \\
\text { Residual } \\
\text { Total }\end{array}$ & $\begin{array}{l}115.946 \\
86.972 \\
202.917\end{array}$ & $\begin{array}{l}2 \\
372 \\
374\end{array}$ & $\begin{array}{l}43.486 \\
.312\end{array}$ & 139.520 & $.000^{\mathrm{b}}$ \\
\hline Model 1 & \multicolumn{2}{|c|}{ Unstandardized Coefficients } & $\begin{array}{l}\text { Standardized } \\
\text { Coefficients }\end{array}$ & \multirow[t]{2}{*}{$\mathrm{T}$} & \multirow[t]{2}{*}{ Sig. } \\
\hline & B & d. Error & Beta & & \\
\hline
\end{tabular}




\begin{tabular}{|c|c|c|c|c|c|}
\hline (Constant) & 1.138 & .195 & & 5.824 & .000 \\
\hline $\begin{array}{l}\text { Financial } \\
\text { Inclusion }\end{array}$ & .583 & .049 & .561 & 12.010 & .000 \\
\hline $\begin{array}{l}\text { Social } \\
\text { Inclusion }\end{array}$ & .149 & .046 & .151 & 3.226 & .001 \\
\hline
\end{tabular}

\section{Relationship between Financial Inclusion and Social Inclusion}

Result in Table 2 indicates that social inclusion $\left(r=0.543^{* *}\right)$ is positively and significantly related with the financial inclusion. The relationship was positive which implies that the more women have access to finance, the more they likely to be socially inclusive. This indicates that financial inclusion cannot be achieved without social inclusion.

Therefore, the null hypothesis which states there is no significant relationship between financial inclusion and social inclusion is rejected, while alternative hypothesis is accepted.

Table 2: Correlations

\begin{tabular}{|ll|l|l|}
\hline & & $\begin{array}{l}\text { Financial } \\
\text { inclusion }\end{array}$ & Social inclusion \\
\hline Financial & Pearson Correlation & 1 & $.543^{* *}$ \\
Inclusion & Sig. (2-tailed) & & .000 \\
& $\mathrm{~N}$ & 375 & 375 \\
Social & Pearson Correlation & $.543^{* *}$ & 1 \\
inclusion & Sig. (2-tailed) & .000 & \\
& $\mathrm{~N}$ & 375 & 375 \\
\hline
\end{tabular}

**. Correlation is significant at the 0.01 level (2-tailed).

\section{Conclusion}

This study examined the influence of financial inclusion and social inclusion on the performance of women-owned businesses in Lagos State, Nigeria. Findings from the empirical results indicate that financial inclusion and social inclusion were joint predictors of women-owned businesses performance. Study also confirmed that social inclusion has positive and significant relationship with financial inclusion. This indicates that financial inclusion cannot be achieved without social inclusion. This study gives a signal to the government to have policies in place that will encourage women to have access to education,

rights to property, access to leadership role, access to business loans, access to mobile banking and gender equality in Nigeria.

\section{Recommendations}

Based on the findings and conclusion, the following recommendations are made;

1. Government should have a policy in place through its financial regulator to encourage financial institutions to diversify their branch networks in the country, the value transacted through agency banking units and the amount transacted through internet banking across the country.

2. Promotion of financial education and financial literacy among women entrepreneurs should be encouraged in all local governments in Nigeria.

3. Women should be encouraged to have better opportunities to rise to the top in all areas of finance, politics and administration.

4. Government should have policies and regulatory frameworks in place that will close the gender gap in financial inclusion and social inclusion.

5. Government should enact a law that will grant women equal rights to property in order for them to expand their economic opportunities. 


\section{References}

1. Ademola, A.O (2016). Performance impact of Non-Institutional Factors and Financial Management Practices on Women-Owned Micro Enterprises in Oyo State. Unpublished PhD of Ladoke Akintola University of Technology, Ogbomoso, Nigeria.

2. Aker, J., Boumnijel, R., McClelland, A., \& Tierney, N. (2014). Payment Mechanisms and Anti-Poverty Programs: Evidence from a Mobile Money Cash Transfer Experiment in Niger. Tufts University.

3. Akpodono, O.S. (2016). Female Entrepreneurship and Economic Development in South-East, Nigeria. $\mathrm{PhD}$ thesis of University of Nigeria.

4. Arjan, de Haan. (2016). Social inclusion and structural transformation Concepts, measurements and tradeoffs. Working Paper for International Development Research Centre, Ottawa.

5. Ashraf, N, Dean K., \& Wesley, Y. (2010). Female Empowerment: Impact of a Commitment Savings Product in the Philippines_, World Development, Elsivier, 38( 3); 333-344.

6. Bruhn, M. (2009). Female-Owned Firms in Latin America: Characteristics, Performance, and Obstacles to Growth Policy Research Working Paper (Vol. 5122). Washington, DC: World Bank.

7. Bruhn, M. \& McKenzie, D. (2013). Entry Regulation and Formalization of Microenterprises in Developing Countries. Policy Research Working Paper (Vol. 6507). Washington, DC: World Bank.

8. Central Bank of Nigeria (2009). Measuring Nigerian's Financial Inclusion Strategy. www.cenbank.com.

9. Centre for Financial Inclusion (2013). Financial Inclusion: How best can it be strengthened? Business World Intelligence. www.businessworld.com.

10. Chakrabarty, K.C. (2012), "Financial Inclusion: Issues in Measurement and Analysis", Keynote address, BIS-BNM Workshop on Financial Inclusion Indicators, Kuala Lumpur, November.

11. Clark, H. (2013). "Financial Inclusion and HIV/AIDS: Some issues for Consideration for the Workshop on Micro-Finance and HIV/AIDS". Journal of Parker, 2(3): 23-26.

12. Daniel, C. (2001). Integrated programme for social inclusion in Santo Andre, Brazil

13. Demirguc-Kunt, A, Klapper, L \& Singer, D. (2013). "Financial Inclusion and Legal Discrimination Against Women: Evidence from Developing Countries.” World Bank Policy Research Paper 6416.

14. Duflo, E. (2012). Women Empowerment and Economic Development. Journal of Economic Literature, 50(4), 1051-1079.

15. Duryea, S., \& Morales, M. (2011). Effects of the Global Financial Crisis on Children's School and Employment Outcomes in El Salvador. Development Policy Review, 29(5), 527-546.

16. Financial Action Task Force (FATF) (2011). Anti-Money Laundering and Terrorist Financing Measures and Financial Inclusion. FATF, Paris.

17. Hallward-Driemeier, M. (2013). Enterprising Women: Expanding Opportunities in Africa. Washington DC: The World Bank

18. ILO (2015). Women in business and management: gaining momentum. Retrieved from https://sustainabledevelopment.un.org/content/.../1770ILO\%20Report\%202015.pdf 
19. Kalpana, R. A. (2016). The Role of Women Entrepreneurs in Establishing Sustainable Development in Developing Nations. World Review of Business Research. 6 (1) $161-178$

20. Kjeldson. J \& Nelson, K. (2000). The Circumstance of women entrepreneurship.retrieved from http://www.ebstdk/publication/raporter/womenentrepreneur/kapo4.html.

21. Laxmi, P. (2012). Being A Woman Teacher In Nepal: Experiences Of Social Exclusion And Inclusion. $\mathrm{PhD}$ thesis of Kathmandu University, Nepal.

22. Leduc, B. (2005). Equity Based Approach: Promoting gender equality and social inclusion training manual III. Kathmandu: Canadian Centre for International Studies and Cooperation (CECI).

23. Manandhar, M. D. (2008). Policy debates on social inclusion programme - Concept note. Retrieved December 28, 2009, from Social Inclusion research fund: http://www.socialinclusion.org.np.

24. Minniti, M., and Naudé, W. (2010). What Do We Know About The Patterns and Determinants of Female Entrepreneurship Across Countries. European Journal of Development Research, 22(3), 277-293.

25. McKinsey Global Institute (2015). The Power of Parity: How Advancing Women's Equality Can Add \$12 Trillion To Global Growth. Retrieved from www.mckinsey.com/mgi.

26. Munoz, J. (2010). Contemporary Micro-enterprise: Concepts and Cases.Cheltenham: EdwardElgar Publishing . retrieved from www.elgar.com/bookentry_mainlasso

27. Ndubusi, F. (2004). "Bankers List Financing Alternatives For SMEs, In CBN Seminar On Small and Medium Industries Equity Investments Scheme". http/www.CBN/Org./2004/Maritime.

28. Nwanko, O and Nwanko, N.O (2014). Sustainability of Financial Inclusion to Rural Dwellers in Nigeria: Problems and Way Forward. Research Journal of Finance and Accounting, 5(5); 24-31.

29. Oboh, G.A. (2004). Contemporary approaches for Financing Micro, Small and medium Enterprises in Nigeria. conference on SMEs Development held at the international Conference Centre, Abuja, Nigeria. July 19-22.

30. Odeh, O. (2005). The Impact of Federal Government Reform Programme on the Development of the SMEs Sector. A Paper Presented at the National Seminar on Facilitating Easy Accessibility to the SMEEIS Funds by SME Operators. Lagos, 10-11, October, 2005.

31. Rangarajan, C. (2008), Report of the Committee on Financial Inclusion, National Bank for Agriculture and Rural Development (NABARD), Mumbai, January.

32. Rao, V \& Walton, M.( 2004). Culture and Public Action. Palo Alto, CA: Stanford University Press.

33. Seel, A. (2007). Social inclusion: Gender and equity in education SWAPS in South Asia. Kathmandu, Nepal: United Nations Children's Fund, Regional Office for South Asia.

34. Sharma, A.G., Sapnadua, \& Hatwal, V (2012). Microenterprise Development and Rural Women Entrepreneurship: Way for Economic Empowerment. Journal Economics and Management. 1(6), 20-45.

35. Silver, H. (2007). The process of social exclusion: the dynamics of an evolving concept. . Rhode Island, USA: Department of Sociology, Brown University.

36. Small and Medium Enterprises Agency of Nigeria (SMEDAN) (2009) SME Success Digest. 3(1), 4-6.

37. Stephen, M. (2011). Promoting Responsible Financial Inclusion: A Risk-based Approachto Supporting Mobile Financial Services Expansion. Banking \& Finance Law Review, pp. 329-343. 
38. United Nations (2014). Resolutions: Female Entrepreneurs Are Key to Sustainable Global Development, United Nations Foundation. Available http://www.unfoundation.org/blog/female-entrepreneurs.html.

39. Vossenberg, S. (2013). Women Entrepreneurship Promotion in Developing Countries: What explains the gender gap in entrepreneurship and how to close it. Maastricht School of Management Working Paper Series, (2013/08).

40. Wasihun, P., \& Paul, I. (2010). Growth Determinants of Women Operated Micro, Small and Medium Enterprises in Addis Ababa. Journal of Sustainable Development in Africa. 2(6), 70-85. 